\title{
Clémence-Auguste Royerová a vznik sociálního darwinismu
}

\author{
Ivo Budil \\ Metropolitní univerzita Praha, Dubečská 900/10, 10031 Praha 10 - Strašnice \\ Do redakce doručeno 8. listopadu 2016; k publikaci přijato 12. května 2017
}

\section{CLÉMENCE-AUGUSTE ROYER AND THE EMERGENCE OF SOCIAL DARWINISM}

\begin{abstract}
The role of French scholar Clémence-Auguste Royer, the first translator of Darwin's Origin of Species into French, in the rise of Social Darwinism will be critically evaluated in a broader historical and intellectual context of late Second Empire and the first decades of the French Third republic. Clémence-Auguste Royer who has been neglected or marginalized in the classical surveys of the early development of Darwinism in the second half of the nineteenth century contributed significantly to the emergence of modern French anthropological community and to the public debates on gender and race at the dawn of modern French political culture. Her controversial interpretation of Darwinism anticipated the rise of racial and eugenic radical and extremist movements after the First World War.
\end{abstract}

KEY WORDS Clémence-Auguste Royer; Pascal Duprat; Charles Darwin; Social Darwinism; Race; Racial ideology

ABSTRAKT Úloha, kterou sehrála Clémence-Auguste Royerová, první překladatelka Darwinova díla $O$ původu druhů do francouzštiny, při zrodu sociálního darwinismu, bude kriticky posouzena v širším historickém a intelektuálním kontextu pozdního Druhého císařství a francouzské Třetí republiky. Clémence-Auguste Royerová, která byla přehližena nebo marginalizována v klasických přehledech raného vývoje darwinismu ve druhé polovině devatenáctého století, významně přispěla ke vzniku moderní francouzské antropologické komunity a k veřejným debatám o genderu a rase na úsvitu moderní francouzské politické kultury. Její kontroverzní výklad darwinismu předznamenal vzestup rasových a eugenických radikálních a extremistických hnutí po první světové válce.

KLÍČOVÁ SLOVA Clémence-Auguste Royerová; Pascal Duprat; Charles Darwin; sociální darwinismus; rasa; rasová ideologie

André Béjin napsal, že francouzská literátka, překladatelka a badatelka Clémence-Auguste Royerová si plně zaslouží označení první představitelka a průkopnice sociálního darwinismu (Bernardini 1997, 74). ${ }^{1}$ Je to konstatování poněkud překvapivé, protože zmíněná autorka je v současné době prakticky zapomenuta. Za sto čtrnáct let, které uplynuly od jejího úmrtí, byla této výrazné postavě intelektuálního a veřejného života prvních desetiletí francouzské třetí republiky, jíž Ernest Renan přiznal „téměř“ genialitu, věnovány pouze dvě odborné monografie: Clémence Royer: philosophe et femme de science (1985) od Geneviève Fraisseové a Almost a Man of Ge-

1 Termín sociální darwinismus prosadili (s negativní konotací) na počátku dvacátého století Collin Wells a Jacques Novicow (Wells 1907). nius: Clemence-Auguste Royer. Feminism and Nineteenth-Century Science Lives of Women in Science (1997) od Joy Dorothy Harveyové, jež se zaměřila především na genderové aspekty zapojení žen do vědeckého výzkumu na sklonku devatenáctého století. Skutečnost, že Clémence-Auguste Royerová jako první formulovala základní teze sociálního darwinismu a s dramatickou upřímností z nich vyvodila drastické ideologické důsledky, nebyla $\mathrm{v}$ plné míre ve většině historických přehledů zohledněna. Mlčení je někdy výmluvnější než hlasitý pokřik. A jak věděl již Sigmund Freud, to, co vytěsňujeme z našeho vědomí, o nás často podává mnohem autentičtější svědectví než nejsofistikovanější rétorika. Jak uvidíme v následujícím výkladu, „zapomenuti“ Clémence-Auguste Royerové bylo do značné míry důsledkem ideologického programu francouzské Třetí republiky. 


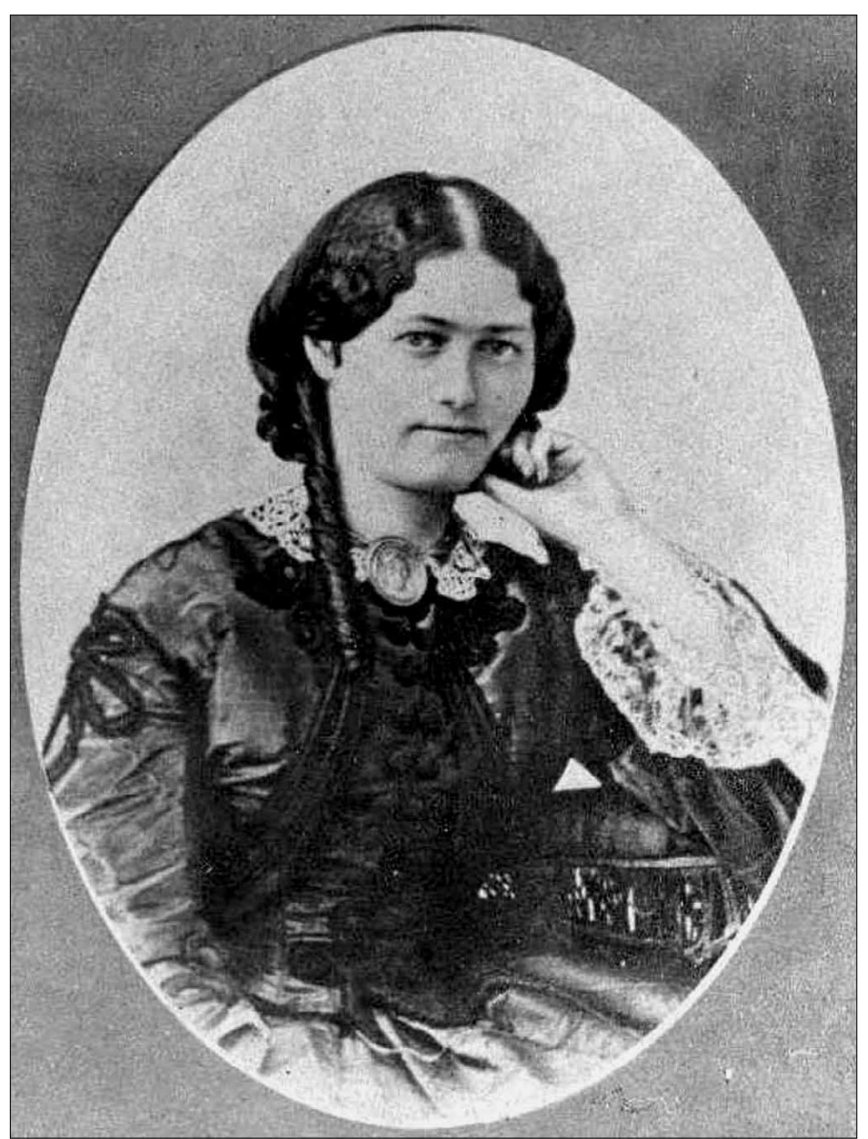

Obr. 1. Fotografie Clémence-Auguste Royerové pořízená Félixem Nadarem $\mathrm{v}$ roce 1865. (http://www.imow.org/community/viewImage?id=6593, 29. 10. 2016)

Za kolébku sociálního darwinismu, to znamená aplikaci teorie př́rodního výběru na moderní lidskou společnost, se považuje Velká Británie. Samotný Charles Darwin neprojevoval o zmíněnou problematiku př́liš velký zájem, i když se občas nezdráhal vyjadřovat $\mathrm{k}$ dané otázce bez jakékoliv sentimentality. Naprŕklad v roce 1871 uvedl v knize $O$ pưvodu člověka (The Descent of Man): „U prírodních národi̊ brzy hynou duševně či tělesně slabí jedinci a ti, kteří prežijí, jsou obyčejně pevného zdraví. Na druhé straně my, civilizovaní lidé, děláme vše co jen je v našich silách, abychom proces vymírání zarazili; stavíme ústavy pro slabomyslné, tělesně postižené a nemocné, zavádíme zákony na ochranu chudých a naši lékaři vynakládají veškerý svůj um, aby zachránili každý život tak dlouho, jak je to jenom možné. Máme dìvod se domnívat, že očkování zachránilo tisíce lidí slabého zdraví, kteří by dřive zahynuli na neštovice, a tak slabí př́islušníci civilizovaných společností dále rozmnožují svi̊j rod. Nikdo, kdo se zabýval chovem domácích zvírat, nebude pochybovat, že to lidské rase musí velice škodit. Je překvapující, jak rychle působí nedostatečná nebo nepravidelná péče na úpadek zdomácnělé rasy - ovšem s výjimkou tèch př́padü, které se týkají člověka samého - a sotva se najde tak nerozumný, aby pokračoval v chovu právě těch nejhorších zviřat" (Darwin 1970, 93). Na druhé straně, když roku 1862 nejbližší Darwinův přítel Joseph Dalton Hooker napsal, že pokládá spis $O$ pưvodu druhư za přesvědčivou obhajobu úlo- hu aristokracie v dějinách, protože si nedokáže představit, že by se demokratické nebo republikánské zřízení dokázalo vypořádat s působením přirozeného výběru, liberálně zaměřený Darwin ironicky odvětil, že neměl ponětí, že je vlastně toryem (Budil 2015, 850).

Historikové obvykle spojují zrod sociálního darwinismu s koncem šedesátých let devatenáctého století. Spoluobjevitel teorie př́rodního výběru Alfred Russel Wallace vystoupil 1. března 1864 na půdě nově založené Londýnské antropologické společnosti (The Anthropological Society of London) s přednáškou nazvanou Pi̊vod lidských ras a starobylost člověka podle teorie prírodního výběru. Wallace prohlásil, že humanismus, filantropie a rozvoj rozumových schopností učinil z „boje o přežití anachronismus. Alfred Russel Wallace byl přesvědčen podobně jako na počátku devatenáctého století utopista Charles Fourrier, že zemi budou v budoucnosti obývat pouze domestikované druhy a že všechna lidská plemena splynou v jednu homogenní rasu (Beecher 1986; Wallace 1864, clxviii-clixx). Sociální darwinismus představoval do značné míry polemickou reakci na uvedené Wallacovo vystoupení. Anglický sociální a politický filozof, ekonom a reformátor William Rathbone Greg, prrítel Alexise de Tocquevilla a Waltera Bagehota, odpověděl Wallacovi v září 1868 na stránkách Fraser's Magazine. Civilizace podle jeho názoru neodstranila přírodní výběr. Mưže se naopak stát jeho obětí, protože v důsledku pomýlené filantropie a sentimentalismu umožňuje, aby se méněcenné sociální skupiny prosadily na úkor fyzicky zdatnějších a zdravějších populací. Konečným důsledkem bude degenerace lidstva. William Rathbone Greg proto navrhl zavedení zákonodárství odstraňující jedince trpící tělesnou a duševní slabostí. Žádoucím ideálem by byla podle Grega společnost skládající se ze světců, mudrců a atletů, Shakespearů, Periklů, Sokratů a Kolumbů. William Rathbone Greg své argumenty vyložil mimo jiné v knize Záhady života (The Enigmas of Life) z roku 1872, v níž ukázal, že darwinismus představuje aplikaci učení Thomase Roberta Malthuse na prŕírodní říši. Sociální darwinismus odhalil a rehabilitoval malthusiánství, které tvořilo skryté teoretické jádro Darwinových a Wallacových tezí (Budil 2014, 71-75).

Souběžně s Williamem Rathbonem Gregem razili cestu sociálnímu darwinismu Herbert Spencer, Charles Loring Brace, Walter Bagehot, Winwood Reade, Cesare Lombroso, Ernst Haeckel nebo Georges Vacher de Lapouge (Budil 2015, 857-877). Synergii sociálního darwinismu a árijské ideologie, která se později stala ideologickým základem nacistického hnutí, shrnul v roce 1876 britský právník a historik Frederick Pollock: „Jako Árijec a darwinista nevidím nejmenši důvod proč šetřit nižši a barbarské rasy kromě toho, že pokud je jejich nahrazování doprovázeno násilím a nenapravitelní barbaři dostanou do rukou ostré predméty, nadřazenou rasu to demoralizuje. Turci s Kruppovými děly a papírovými penězi jsou monstrózností (cit. Parker 1981, 835). Clémence-Auguste Royerová je ve společnosti výše zmíněných osobností zmiňována pouze zř́idka, a to navzdory skutečnosti, že v předmluvě k překladu Darwinova spisu O pưvodu druhư do francouzštiny z roku 1862 předložila šest let před Gregem teoretický 


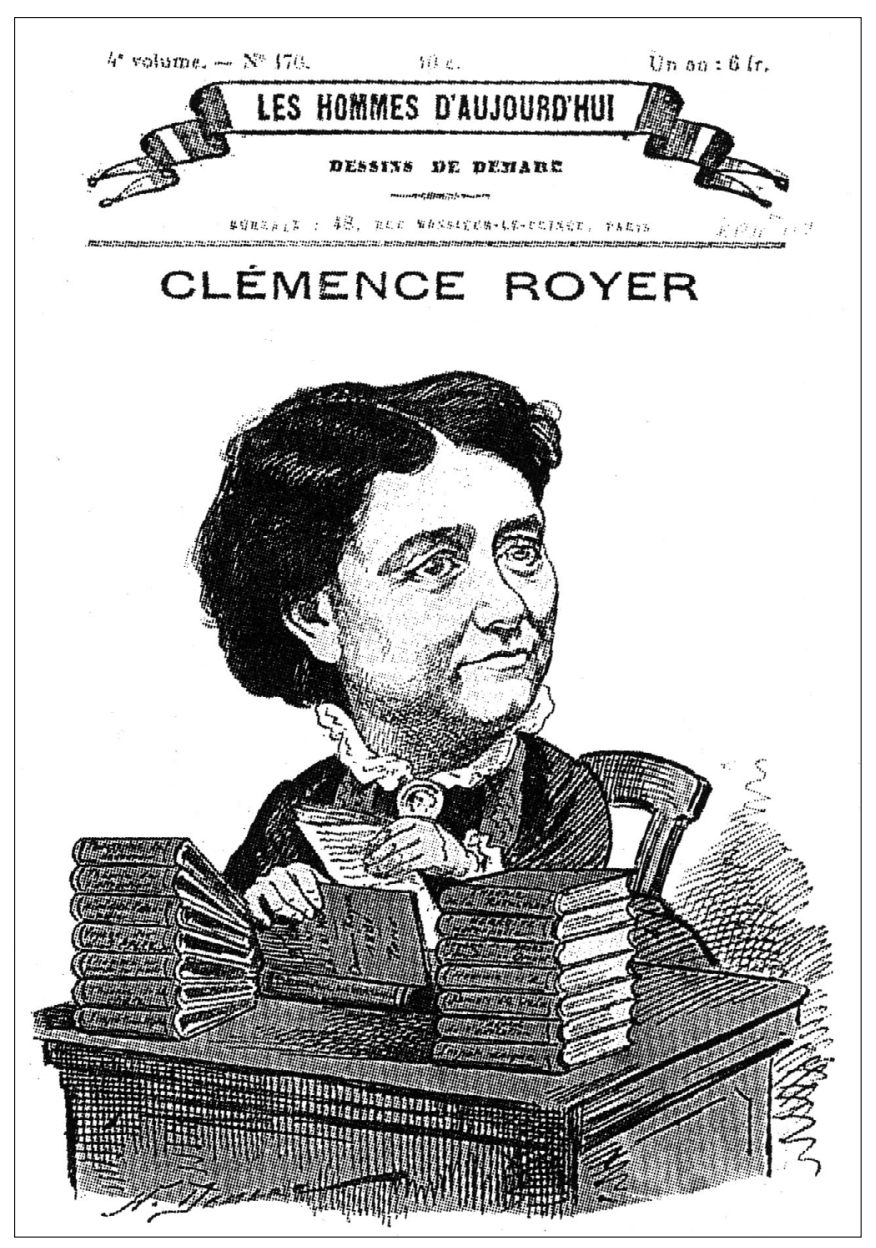

Obr. 2. Karikatura Clémence-Auguste Royerové z roku 1881. (https://en.wikipedia.org/wiki/Cl\%C3\%A9mence_Royer\#/media/File:Clemence_Royer_caricature_1881.jpg, 29.10.2016)

rámec sociálního darwinismu (Budil 2015, 852-857; Budil 2015a, 15-27; Fraisse 1985; Harvey 1997; Hawkins 1997, 124-128; Clark 1981).

Clémence-Auguste Royerová se narodila 21. dubna 1830 v Nantes. Její otec Augustin-René Royer sloužil v posledních třech letech Prvního císařství jako kapitán lehké pěchoty. Po Napoleonově pádu př́sahal věrnost Ludvíku XVIII. V lednu 1831 se kapitán Royer připojil v Bretani k povstání vévodkyně z Berry, které mělo vrátit Bourbony na francouzský trůn, jehož se po červencové revoluci roku 1830 zmocnil Ludvík Filip Orleánský (Harvey 1997, 6). V roce 1832 se Augustin-René Royer účastnil společně s jinými legitimistickými aristokraty v Praze slavnostní korunovace francouzského „vzdorokrále“ Jindřicha V. Matka Joséphine-Gabrielle Audouardová pocházela ze staré bretaňské námořnické rodiny. Rebelové byli orleánským režimem poraženi a kapitán Royer, který byl odsouzen k smrti, uprchl do Švýcarska. Zde se $\mathrm{k}$ němu poblíž Lausanne připojila rodina. Roku 1835 se Augustin-René Royer vrátil zpět do Francie, aby čelil soudnímu líčení. Soudci byli shovívaví a kapitánovi byl vyměřen trest žaláře $\mathrm{v}$ délce několika měsíců. Po propuštění obdržel penzi ve výši jednoho tisíce čtyř set franků. Usadil se v Paříži, kde
Clémence-Auguste Royerová prožila dětství. I když se později se svým otcem názorově rozešla, vždy si vážila jeho „loajality hraničící s donkichotstvím“. Označila jej za „liberálního legitimistu Chateaubriandova typu“ neboli "monarchistu rozumem, přivržence Bourbonů ctí a republikána povahou“ (Harvey 1997, 9). Otec nicméně přišel kvưli neúspěšnému podnikání o většinu peněz a rodina byla nucena přesídlit na venkov do La Mayenne.

Desetiletou Royerovou poslali do Sacré-Coeur du Mans, klášterní školy pro dívky z aristokratických rodin. Po třech letech prodělala vážnou psychickou krizi a společně s rodiči se opět přestěhovala do Pařiže. Tak jako mnoho dospívajících dívek té doby Royerová četla román Corinne od Madame de Staël a snila o divadelní dráze. Otec opustil rodinu a odešel definitivně do La Mayenne, kde v srpnu 1849 zemřel. Clémence-Auguste Royerová, která obdržela menší dědictví, byla nyní svobodná. Nijak netoužila se vdát. Během revoluce 1848 opustila monarchistické přesvědčení a stala se rozhodnou republikánkou. Pozbyla zbytky katolické víry. Po třech letech studia aritmetiky, hudby a francouzštiny obdržela prestižní certifikát vydávaný magistrátem (Hôtel de Ville), který ji opravňoval vyučovat na střední škole. Ve vyšší vzdělání ženy v tehdejší Francii nemohly doufat.

Clémence-Auguste Royerová si přála působit na Britských ostrovech, kde byla po francouzských učitelkách poptávka. Sarah Lewisová jí nabídla místo v soukromé dívčí škole, kterou založila v Haverfordwestu ve Walesu. Royerová zahájila výuku v lednu 1854. Její znalost angličtiny byla zpočátku omezená, ale dělala rychlé pokroky. Po vypršení smlouvy na jaře 1855 se Clémence-Auguste Royerová vrátila zpět do Francie, kde působila jako pomocná učitelka $\mathrm{v}$ Touraine a Beauvais. Tím její pedagogická dráha skončila. Důvodem bylo přijetí zákona, který formálně zrušil ve Francii laické dívčí střední školy. Certifikát, který Royerová získala ještě za Druhé republiky, pozbyl platnosti (Harvey 1997, 40).

Royerová, která zdědila po otci částku sedmi tisíc franků, odcestovala v červnu 1856 přes Lyon do Lausanne (Harvey 1997, 42). Zprvu si ve Švýcarsku vydělávala jako švadlena, ale záhy si pronajala malý pokoj v selské usedlosti v Praz-Perey v Cully na úbočí Savojských Alp deset kilometrů od Lausanne. Zde strávila dva roky intenzivním samostudiem, během nichž využívala zdroje $\mathrm{z}$ dobře zásobené veřejné knihovny $\mathrm{v}$ Lausanne. Počínaje četbou německých teologických textů přes Kanta, Rousseaua, Diderota a Voltaira dospěla k problematice archaického člověka a otázce přechodu mezi zvírecím a lidským světem (Harvey 1997, 44). Nezanedbávala ani matematiku a atomovou teorii, $\mathrm{k}$ níž se opět vrátila na sklonku života. Oblečena do indických šatů s venkovským slamákem na hlavě působila bezpochyby na místní obyvatele excentricky.

V lausannské Akademii ( $\mathrm{z}$ níž se později stala univerzita) se $\mathrm{v}$ roce 1858 seznámila se čtyřiačtyřicetiletým Pascalem Dupratem (1815-1885), bývalým vlivným francouzským poslancem, jedním $\mathrm{z}$ řady republikánů, kteří odešli do exilu po vzniku císařství. Přednášel v Akademii a vydával v Lausanne literární periodikum La Revue Philosophique et Littéraire a časopis Le Nouvel Économiste. Pascal Duprat byl ženat 


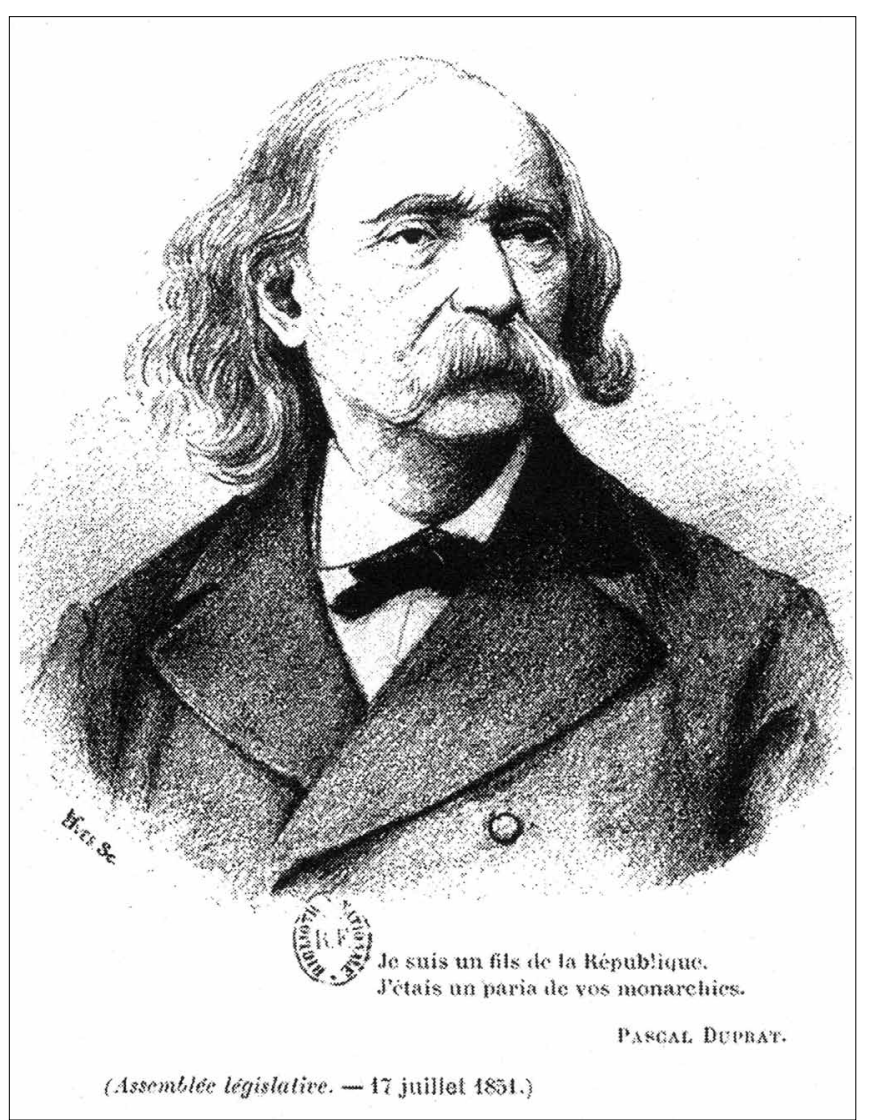

Obr. 3. Portrét Pascala Duprata kolem roku 1880. Pramen: Nigoul 1887. https://en.wikipedia.org/wiki/Cl\%C3\%A9mence_Royer\#/media/File:Pascal_Duprat_ca1880.jpg, 29.10.2016)

a jeho manželka a dcera se $\mathrm{k}$ němu připojily v Lausanne. Měl již za sebou pozoruhodnou politickou a publicistickou dráhu včetně pedagogického působení v Alžírsku. Studoval v německém Heidelbergu a hovořil arabsky, španělsky a italsky. Záhy se stal milencem a mentorem o patnáct let mladší, stále nepříliš vzdělané a tvárné Royerové, která ve své dobrovolné izolaci toužila po intelektuálních podnětech. Pascal Duprat jí poradil, aby napsala román. Royerová pracovala čtrnáct hodin denně, aby tomuto úkolu dostála. Výsledkem byla Řecká dvojčata (Les Jumeaux d'Hellas), romantické dvousvazkové dílo o tisíci stránkách vyznačující se značně chaotickým dějem. Royerová je sepsala roku 1858, ale bylo vydáno za malé pozornosti čtenářu až o šest let později v Bruselu. Francouzské úřady knihu kvưli jejímu výrazně antiklerikálnímu zaměření zakázaly. Autorka se inspirovala Corinnou od Madame de Staël, Posledními dny Pompejí Bulwera-Lyttona nebo romány Alexandra Dumase, George Sandové, Chateaubrianda a Voltaira (Harvey 1997, 27). V románu byla obsažena řada autobiografických prvků, včetně téma rozchodu s katolickou církví, zaujetí moderní vědou, stylizace do role ženské rebelky a obdiv k intelektu a charizmatu Pascala Duprata.

$\mathrm{V}$ roce 1858 Clémence-Auguste Royerová zahájila vlastní přednášky o př́rodní filozofii na půdě Akademie pro ženské posluchače. Navzdory přetrvávající oblibě Cuvierovy ško- ly neskrývala lamarckistické a protiklerikální názory. Muži neměli do sálu př́stup, protože Lausanne bylo univerzitním městem a Royerová se údajně obávala, že by studenti během výkladu rušili (Harvey 1997, 47). Royerová byla přesvědčena, že by ženy neměly ve sféře vědy slepě napodobovat silnější pohlaví, ale pokusit se o vlastní femininní verzi vědeckého bádání. Teprve díky ženskému vlivu věda prostoupí celou společnost a osloví od raného dětství všechny sociální vrstvy (Harvey 1997, 53-54). Na jaře 1861 se Clémence-Auguste Royerová vypravila do Paříže, kde se seznámila s proslulou aristokratkou hraběnkou Marie d'Agoultovou (1805-1876), bývalou blízkou př́telkyní Franze Liszta, jejíž salón byl hlavní baštou republikanismu v císařské Francii. Marie d'Agoultová, rozená Marie de Flavigny, byla rovněž známou spisovatelkou píśící pod pseudonymem Daniel Stern.

Kanton Vaud, jehož hlavním městem bylo Lausanne, uspořádal roku 1860 konferenci o dani z př́jmu, což byla problematika, o níž tehdy diskutovali nejpřednější ekonomové doby. Podle Dupratovým vlivem Royerová obrátila pozornost k ekonomickým otázkám. Když kanton Vaud v návaznosti na zmíněnou konferenci vyhlásil soutěž o nejlepší studii pojednávající o teorii daní, získala Royerová prací Théorie de l'impôt ou la dîme social druhé místo, hned za pojednáním, které zaslal socialista Pierre-Joseph Proudhon (Clark 1981, 28). Od května 1862 publikovala Clémence-Auguste Royerová články a recenze v Journal des Économistes. Účastnila se kongresů Asociace pro sociální vědy v Belgii, Švýcarsku a Nizozemí.

Mezitím ve Velké Británii uveřejnil v roce 1859 Charles Darwin převratné dílo $O$ původu $d r u h u ̊$, ve kterém vyložil svoji (a Wallacovu) teorii prrírodního výběru. Jako první referoval ve Švýcarsku o uvedené knize v následujícím roce v periodiku Bibliothèque Universelle geolog, paleontolog a lingvista François Jules Pictet. Následovala nadšená recenze, kterou uveřejnil v Revue Germanique profesor Ženevské univerzity René Édouard Claparède, spolužák německého embryologa a pozdějšího darwinisty Ernsta Haeckela. Carl Vogt působící v ženevském Muzeu přírodních dějin náležel rovněž $\mathrm{k}$ propagátorům evoluční teorie. Přeložil do němčiny Pozůstatky prírodních dějin stvoření (Vestiges of the Natural History of Creation) z roku 1844 od Roberta Chamberse, nejvlivnější evolucionistický spis před vystoupením Charlese Darwina.

Charles Darwin usiloval z prestižních důvodů o překlad svého díla do francouzštiny. Oslovil irskou spisovatelku a překladatelku Louisu Bellocovou, rozenou Swantonovou (1796-1881), která se vdala za francouzského malíře Jeana-Hilaira Belloca (1786-1866) a žila ve Francii. Jejím vnukem byl slavný spisovatel Hilaire Belloc (1870-1953). Louisa Bellocová, která přeložila do francouzštiny Chaloupku strýčka Toma od Harriety Beecherové, Darwinovu nabídku odmítla. Pierre Talandier, jenž přednášel na vojenské akademii v Sandhurstu, měl značný zájem na realizaci překladu, ale jeho úzké vztahy s radikálními socialisty, např́klad Louisem Blancem, odradily potenciální nakladatele (Harvey 1997, 63).

Není zřejmé, z jakého důvodu padla volba na převedení O původu druhů do francouzštiny na relativně málo známou Clémence-Auguste Royerovou. Důležitou úlohu bezpochyby 
hrála znalost angličtiny. Jejím odborným poradcem a konzultantem $\mathrm{v}$ prrírodovědných záležitostech měl být René Édouard Claparède. Skutečnost, že odborné těžiště Royerové spočívalo v ekonomických vědách, představovalo spíše výhodu, protože darwinismus byl tehdy vzdělanci vesměs pokládán za aplikaci teorií anglického ekonoma Thomas Roberta Malthuse na živočišnou říši. Charles Darwin požádal 10. září 1861 nakladatele Johna Murraye, aby zaslal výtisk třetího vydání $O$ piovodu druhů Clémence-Auguste Royerové do Lausanne.

Text, který Clémence-Auguste Royerová samostatně vytvořila (René Édouard Claparède byl dlouhodobě nemocen), nebyl pouhým překladem od nezkušené autorky, ale svébytnou a provokativní interpretací Darwinovy teorie předznamenávající mnohé intelektuální podněty, které se $\mathrm{v}$ následujících desetiletích v souvislosti s působením Darwinovy školy objevily. K Darwinově nelibosti Royerová opatřila Darwinovu knihu pozměněným poznámkovým aparátem a připojila k ní rozsáhlý a intelektuálně značně eklektický úvod, ve kterém nijak neskrývala radikálně ateistický a volnomyšlenkářský světonázor. Novověké dějiny lidstva jsou podle Royerové historií osvobození lidského rozumu od Bacona, přes Descarta, Newtona, Leibnize až po Darwina (Darwin, 1862, xxxviii). Charlese Darwina označila za „štastného amatéra“, muže, jehož erudice se nemohla měřit s géniem Georgese Cuviera nebo Geoffroye Saint-Hilaira (Darwin, 1862, xlviii). Shodou okolností učinil převratný objev. Clémence-Auguste Royerová s příznačnou „skromností podotkla, že nezávisle na Darwinovi dospěla k obdobným závěrům (Darwin 1862, 1). Royerová vytkla svým současníkům, že ne zcela docenili obrovský význam Darwinova učení, které ovlivní veškeré sféry lidské intelektuální a morální činnosti a jehož výrazně protikřestanský charakter je nepopiratelný. Royerová souhlasila s Reném Edouardem Claparèdem, který „by byl raději „zdokonalenou opici“ („un signe perfectionné“) než „degenerovaným Adamem“ („Adam dégénéré, Darwin 1862, p. lii). Existoval však další významný aspekt darwinismu, ve kterém Royerová odhalila malthuziánské intelektuální jádro. Podle Royerové jim bylo přehodnocení tradičních politických utopií předpokládajících univerzální rovnost mezi lidmi (Darwin 1862, lxix). Není např́klad možné, aby ve společnosti tvořené menšinou Indogermánů a většinou Mongolů či černochů existovala politická a občanská rovnost (Darwin 1862, lxix). Darwinismus představuje rovněž způsob, jak zastavit tělesný úpadek lidstva (Darwin 1862, lxvi). V této souvislosti Clémence-Auguste Royerová vyzvala ke zvýšení fyzické zdatnosti žen.

Navzdory zdání Royerová nepropagovala eugenickou despocii, která se později realizovala $\mathrm{v}$ rámci nacistického totalitarismu, ale obdobně jako saint-simonista Victor Courtet ${ }^{2}$ byla přesvědčena, že v systému absolutní individuální svobody se

2 Autor knihy Politická věda, založená na vědě o člověku neboli studium lidských ras $z$ filozofického, historického a sociálního hlediska (Science politique, fondée sur la science de lhomme ou étude des races humaines sous le rapport philosophique, historique et social) $\mathrm{z}$ roku 1838.

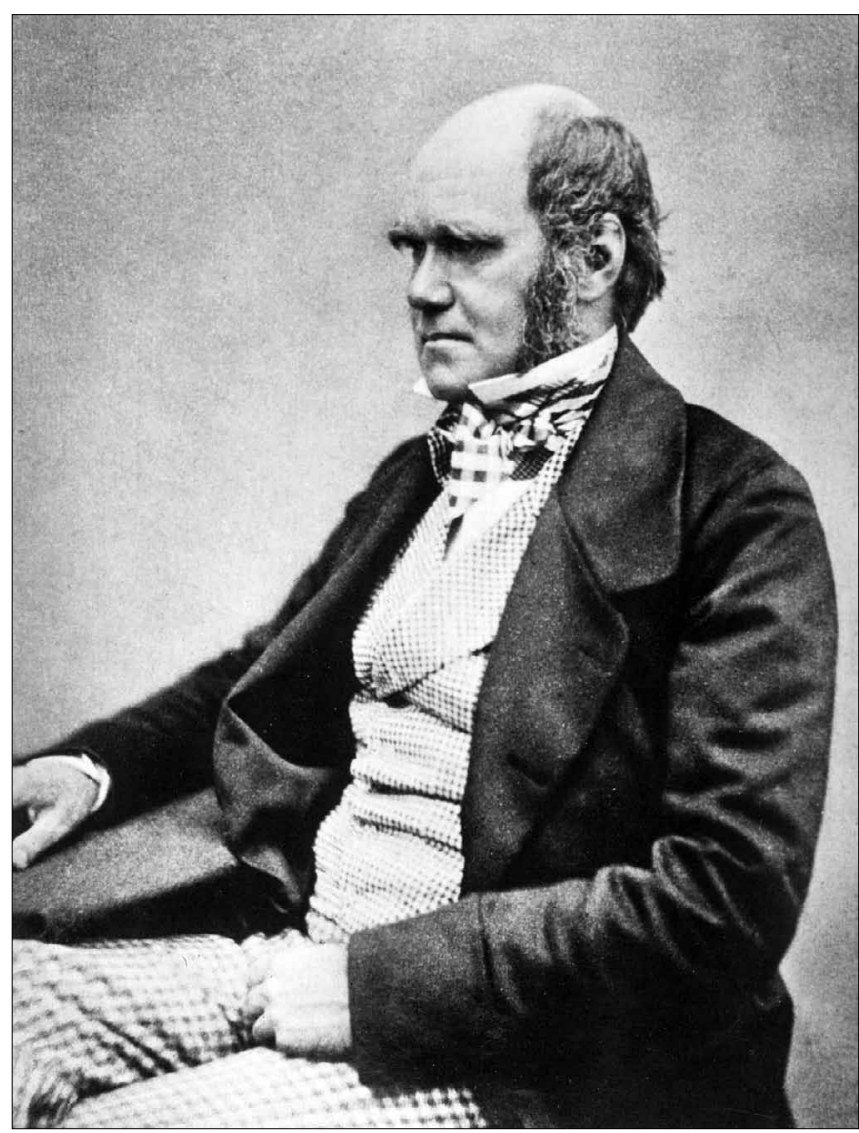

Obr. 4. Charles Darwin na fotografii pořízené kolem roku 1860. (https:// en.wikipedia.org/wiki/1860_Oxford_evolution_debate\#/media/File:Charles_Darwin_seated_crop.jpg, 29.10.2016)

spontánně prosadí politický rád zohledňující skutečné osobní a kolektivní dispozice (Darwin 1870, lxx). Tato aliance mezi rasovou utopií a liberalismem přetrvala $\mathrm{v}$ mnohých intelektuálních a akademických kruzích Západu až do první světové války, kdy byla zastíněna přirozenějším spojenectvím eugeniky a autoritářského státu.

Charles Darwin, v té době usedlý padesátník, byl z Royerové překladu a úvodu částečně rozpačitý a částečně pobavený. Svému americkému příteli botanikovi Asa Grayovi napsal, že Clémence-Auguste Royerová musí být jednou z nejchytřejších a nejpodivnějších žen Evropy. Je přesvědčenou deistkou, nenávidí křestanství a domnívá se, že přirozený výběr objasní morálku, lidskou povahu, politiku, zkrátka úplně vše. Royerová později tvrdila, že jí Darwin poslal děkovný dopis, $\mathrm{v}$ němž uvedl, že pokud by psal tak otevřeně jako ona, byl by „ztracen“. Charles Darwin byl nicméně později vưči Royerové kritičtější a Armandu de Quatrefagesovi sdělil, že překladatelka měla být obeznámenější s př́rodními vědami. To bylo mínění i René Edouarda Claparèda nebo prvních překladatelů Darwina do italštiny Giovanniho Canestriniho a Leonarda Salimbeniho (Harvey 1997, 67-68, 81). Josephu Daltonu Hookerovi si Charles Darwin postěžoval na kvalitu poznámkového aparátu. V roce 1870 , poté, kdy Royerová nezohlednila ve třetím vydání některé změny, které Darwin v textu mezitím 
učinil, s ní Charles Darwin ukončil spolupráci (Harvey 1997, 100-101). Překlad Darwinova díla z pera Clémence-Auguste Royerové navzdory tomu vyšel ve Francii ještě v letech 1882, 1901, 1918 a 1932 (Bernardini 1997, 74).

Francouzské vydání $O$ pưvodu druhủ bylo přijato ambivalentně. Joseph Garnier, prezident Společnosti pro politickou ekonomii, a Arthur Mangin připustili v roce 1863 na stránkách Le Journal des économistes přínos „anglických přírodovědcü“ a obezřetně se vyjádřili $\mathrm{k}$ jejich možnému uplatnění v politické ekonomii. Henri Baudrillard, profesor dějin politické ekonomie a vedoucí redaktor Le Journal des économistes, se v roce 1870 vyslovil mnohem explicitněji proti spekulativnímu odstraňování bariér mezi společenskými a př́rodními vědami (Bernardini 1997, 80-81). Napoleon III. se snažil o sblížení s katolickou církví a antiklerikální postoj, který Clémence-Auguste Royerová spojila $s$ darwinismem, byl v rozporu $s$ oficiální politikou císařského režimu. Ve srovnání s třicátými a čtyřricátými lety devatenáctého došlo ve Francii k odklonu od hospodářského liberalismu ke státnímu etatismu, jenž odporoval liberalismu laissez-faire, který Royerová zastávala. Když ji později Paul Lafargue požádal, aby přeložila do francouzštiny Marxův Kapitál, odmítla. Nikdy nebyla a nehodlala být socialistkou (Harvey 1997, 115). Intelektuálně vlivné periodikum La Revue des deux mondes často varovalo před nebezpečnou vlnou "přírodovědného“ materialismu a ve stejném duchu působila rovněž idealistická filozofie Victora Cousina. Většina francouzských prŕrodovědců zastávala teorii kataklyzmat Georgese Cuviera a evolucionistická teorie př́rodního výběru se prosazovala ve Francii ve srovnání s anglosaským prostředím relativně pomalu (Clark 1981, 28). K předním oponentům Charlese Darwina náležel např́klad proslulý fyziolog a neurolog Jean Pierre Flourens nebo zakladatel moderní francouzské antropologie Paul Broca (Harvey 1997, 77-79). Mezi francouzskými antropology a etnology převládal polygenismus předpokládající, že se lidstvo vyvinulo z několika odlišných druhů.

V roce 1865 se Royerová přestěhovala do Paříže (kde s ní tajně v jejím bytě žil tři měsíce Pascal Duprat, který měl zakázáno překročit francouzské hranice). Oba milenci později pobývali v Turíně a Florencii, kde 12 . března 1866 přišel na svět syn René. Royerová mezitím přispívala do radikálního republikánského časopisu La Pensée nouvelle. Roku 1869, zatímco Pascal Duprat odejel jako korespondent do Španělska, se Clémence-Auguste Royerová usídlila natrvalo se synem v Paříži. V následujícím roce byla Royerová jako první žena zvolena díky přímluvě Armanda de Quatrefagese a Julese Gavarreta členkou prestižní Pařížské antropologické společnosti, kterou založil v roce 1859 Paul Broca (Hawkins 1997, 124). Pravidelně docházela na zasedání a publikovala v Bulletin de la Société d'Anthropologie de Paris. Již roku 1860 Clémence-Auguste Royerová vstoupila do Etnografické společnosti vedené Léonem de Rosnym (Harvey 1997, 117).

Výsledkem několikaletého úsilí byla studie Pơvod člověka a společnosti (Origine de l'homme et des sociétés), kterou Clémence-Auguste Royerová uveřejnila roku 1870. Pojednávala o tématu, jemuž Charles Darwin věnoval knihu O pưvodu člo- věka (The Descent of Man) až v následujícím roce (Hawkins 1997, 125-126). Clémence-Auguste Royerová spojila darwinistický výklad lidské evoluce s rasovou hierarchií. Zdůraznila, že australští domorodci, indiáni, Arabové nebo Číňané nedokáží kvůli nedostatku vnitřních biologických a mentálních dispozicí překonat vývojové stádium, ve kterém se nacházejí. Toho byla schopna pouze evropská větev árijské rodiny (Royer 1870, 77). Árijci představují vrchol evoluce lidstva (Royer 1870, 99-100). Válečnický a dobyvatelský instinkt, který je lidskou přirozenou výbavou, napomáhá podle Royerové pokroku lidstva. Díky němu si rasově nadřazení bojovní árijští nomádi podmanili v Indii místní drávidské obyvatelstvo a dobyli další končiny světa, kde vybudovali impozantní civilizace (Royer 1870, 533-534). Pokračováním zmíněné civilizační mise je novodobý kolonialismus, který by ale neměl vyústit do míšení ras, jež Royerová považovala obdobně jako Robert Knox, Arthur Gobineau nebo Ernest Renan za nemorální (Royer 1870, 532). Pochybovala, že by rasově smíšené populace dokázaly vytvořit stabilní politické útvary (Royer 1870, 498-499, 536-537). Clémence-Auguste Royerová byla přesvědčena, že ve vztahu $\mathrm{k}$ „nižším“ rasám je třeba se zbavit jakéhokoliv sentimentalismu a falešného humanismu. Podřadná plemena jsou uvězněna $\mathrm{v}$ primitivním a animálním bezčasí, ze kterého je nedokážeme vysvobodit. Jde o lidské fosilní relikty bez naděje a budoucnosti (Royer 1870, 221-224). Clémence-Auguste Royerová méně skrytou a explicitnější rétorikou vyjádřila koloniální étos Třetí republiky, který formuloval po roce 1871 naprŕklad Paul Leroy-Beaulieu ve spise $O$ kolonizaci (De la colonisation, 1874). Francouzský státník Georges Clemenceau byl obezřetnější. Uvědomil si, že po německém vítězství v prusko-francouzské válce se "germánský triumfalismus" oděl do pseudo-darwinistické rétoriky „dominance silnějšího“. V době mocenského úpadku Francie se argumentace „rasovou nadřazenosti' " mohla velmi snadno obrátit proti Paříži (Harvey 1997, 95).

V návaznosti na Arthura Gobineaua vyzdvihla Clémence-Auguste Royerová existenci systému kast u archaických Árijců, jejichž válečnická kasta byla nejúčinnějším nástrojem expanze. Římská říše podlehla právě proto, že se zmíněné instituce zbavila, zatímco u barbarských Germánů zůstala zachována. Pokud má být Francouzská revoluce podle Royerové skutečným historickým předělem $\mathrm{v}$ dějinách lidstva, pak by zrušení feudálních privilegií 4 . srpna 1789 mělo znamenat odstranění anachronické a parazitující aristokracie, která již neplnila svoji sociální úlohu. Zároveň se měl otevřít prostor pro revitalizační vzestup nové válečnické a dobyvatelské kasty, skutečné obrozené aristokracie, ztělesňující árijské ctnosti. Clémence-Auguste Royerová zdůrazňovala řadu let před Theodorem Rooseveltem, že tento úkol je o to naléhavější, protože dominance bílé rasy je ohrožena asertivitou žlutého plemene, (Harvey 1997, 148-149). Alternativa vůči kastovní hierarchii spočívající $\mathrm{v}$ homogenní mase rovnoprávných občanů, $\mathrm{k}$ níž vyzývali Jean-Jacques Rousseau nebo Pierre-Joseph Proudhon, ústí do sociálního rozvratu (Royer 1870, 567-577). $\mathrm{V}$ poslední větě své knihy vyjádřila Clémence-Auguste Royerová víru, že tak, jako se díky „rovnosti v prŕležitostech“ 
a "pokroku prostřednictvím nerovnosti“ vyvinul z nižších druhů člověk, zrodí se $\mathrm{v}$ budoucnosti $\mathrm{z}$ dnešního lidstva „božská rasa, která bude vládnout na zemi spravedlivě, v radosti a v míru“ (Royer 1870, 587).

Po pádu Druhého císařství se politické poměry a ideologické ovzduší ve Francii výrazně změnilo. Pascal Duprat se oficiálně vrátil $\mathrm{z}$ exilu již $\mathrm{v}$ roce $1869 \mathrm{v}$ době krátké liberalizace, jež předcházela vypuknutí prusko-francouzské války. Měl však mnoho nepřátel a jeho opětovné začlenění do politického života nebylo snadné. Podporoval Adolpha Thierse proti Léonu Gambettovi, kterého podezíral z diktátorských sklonů (Harvey 1997, 115). Royerová začala psát nový román (Jeunesse d'une révolte) vycházející z Dupratových zkušeností $\mathrm{z}$ revolučního roku 1848. Dílo ale nedokončila a nedochovala se ani žádná kopie (Harvey 1997, 104). Duprat byl v listopadu 1871 zvolen poslancem Národního shromáždění za Landes. Radikální republikáni mu nezapomněli jeho spojenectvím s Thiersem, strůjcem porážky pařižské Komuny. Duprat pozbýval politického vlivu a přišel o místo v parlamentu.

Nový režim zdůrazňoval svobodu myšlení a vědeckého bádání. Léon Gambetta prohlásil, že republika bude bud' vědecká, anebo vůbec nebude (Clark 1981, 29). Clémence-Auguste Royerová se již v dubnu 1870 účastnila v Pařížské antropologické společnosti živé debaty o významu darwinismu, během níž se střetla s Armandem de Quatrefagesem (Harvey 1997, 107111). Recepce darwinismu, který mnozí badatelé stále zaměňovali s lamarckismem, nebyla ve Francii jednoduchá. Důraz na přirozenou hierarchii, nerovnost, boj o život a nespoutaný liberalismus nekorespondoval s oficiální republikánskou rétorikou. Ve Francii se šírila zejména prostřednictvím Charlese Renouviera Kantova filozofie, odporující darwinistickému materialismu. Emile Littré kritizoval darwinismus a jeho údajné sociální konsekvence (Clark 1981, 31). Na druhé straně jeden $\mathrm{z}$ vůdčích ideologů třetí republiky filolog a historik Ernest Renan viděl v darwinismu - stejně jako Clémence-Auguste Royerová - potvrzení své vlastní celoživotní snahy sladit př́rodní a lidské dějiny. Obdobně Hippolyte Taine, další vưdčí postava intelektuálního života republikánské Francie, byl přesvědčen, že odhalení zákonů přírodního výběru má dalekosáhlý význam pro společenské a historické vědy (Bernardini 1997, 83-84). Proslulý historik a orientalista Edgar Quinet uveřejnil v letech 1869 až 1870 dvousvazkové dílo Stvoření (La Création), ve kterém představil soudobé evoluční teorie. Na rozdíl od Royerové prohlašoval, že by se lidstvo nemělo podřizovat přírodním zákonům přežití nejsilnějšího, ale svojí kreativitou a invencí se vymknout omezením, která rozpoznal na počátku devatenáctého století již Thomas Robert Malthus (Bernardini 1997, 87-88). Konečný triumf darwinismu ve Francii přišel na sklonku sedmdesátých let devatenáctého století s antropologickou školou, kterou ztělesňoval Paul Topinard nebo Abel Hovelacque (Bernardini 1997, 112-119; Conry 1974, 51-107).

Clémence-Auguste Royerová byla $\mathrm{v}$ závěru devatenáctého století nepřehlédnutelnou postavou vědeckého a veřejného života. Na Mezinárodního kongresu o ženských právech konaném roku 1889 vystoupila s přednáškou, ve které zdůraznila potřebu vzdělání žen (zároveň jim však upírala volební právo). Přispívala do feministického listu La Fronde, jenž založila a řídila Marguerite Durandová. Banketu, který byl pořádán roku 1897 na její počest, se zúčastnilo dvě stě padesát významných intelektuálů a veřejných činitelů včetně Georgese Clemenceaua, Anatola France, Émila Zoly nebo Mercellina Berthèllota, vesměs osobností, které se angažovaly v probíhající Dreyfusově afére. Z rukou ministra veřejného vzdělávání obdržela Royerová 12. listopadu 1900 řád Čestné legie.

Pascal Duprat, který byl jmenován francouzským vyslancem v Chile, v Jižní Americe vážně onemocněl a zesnul 17. srpna 1885 na palubě lodi Le Niger během zpáteční plavby do vlasti. Royerová a její syn René, student École Polytechnique, které Duprat finančně podporoval, se ocitli prakticky bez prostředků. Royerová obdržela pouze malou penzi od ministra Paula Berta, jehož požádala o pomoc (Harvey 1997, 156). Její zdravotní stav se zhoršil (trpěla silným astmatem). Roku 1891 se Clémence-Auguste Royerová uchýlila do Maison Galignani, domova pro seniory $\mathrm{v}$ Neuilly-sur-Seine, $\mathrm{v}$ němž přebývala až do své smrti 6. února 1902. René Royer podlehl nemoci jater o šest měsíců později během vojenské služby v Indočíně.

Vzhledem k tomu, že názory Clémence-Auguste Royerové se př́liš nelišily od toho, co zaznívalo z projevů čelních tvưrců veřejného mínění Třetí republiky, není zcela zřejmé, proč došlo v dějinách moderní francouzské vědy $\mathrm{k}$ její marginalizaci. Názor, že při „konspiraci mlčením“ sehrálo hlavní roli její pohlaví, neobstojí, protože éra, kdy měly ženy zapovězen př́istup $\mathrm{k}$ akademické práci, se chýlila ke konci. Royerová dokonce jednou prohlásila, že to, že je ženou, pokládá za výhodu, protože jako muž by se musela odborně specializovat a ztratila by širší přehled (Harvey 1997, 4). Clémence-Auguste Royerová se navíc stala členkou prestižní vědecké společnosti.

Jednou z hlavních příčin jejího opomíjení může být skutečnost, že Clémence-Auguste Royerová přecenila své intelektuální síly. Přehnané ambice ji přiměly zaútočit prrímo na jádro rodícího se scientistického paradigmatu. Skromnost jí ostatně nikdy nechyběla. $\mathrm{V}$ dopise $\mathrm{z}$ 30. dubna 1891 adresovaném antropologu Armandu de Quatrefagesovi, ve kterém se ucházela o cenu Akademie věd, Royerová uvedla, že svými myšlenkami předběhla (dvakrát) Charlese Darwina a Ernsta Haeckela a že navrhla zcela novou teorii původu druhů (Bernardini 1997, 76). Mezi géniem a podivínem bývá občas pouze tenká hranice nastavená nahodilou konstelací a přízní vědeckých autorit. V práci Dobro a morální zákon (Le bien et la loi morale, 1881) Clémence-Auguste Royerová navrhla nový etický systém vyrůstající z ducha darwinismu. Určitý rozruch vyvolala publikace z roku 1883, ve které Royerová zpochybnila samotné Newtonovy zákony. Svoji nejambicióznější studii Stavba světa (Constitution du monde) Clémence-Auguste Royerová uveřejnila v roce 1900. Předložila v ní monistický darwinistický model kosmu, $\mathrm{v}$ jehož rámci dovedla princip př́rodního výběru až na úroveň atomů. Měla to být alternativa vůči Newtonově mechanistickém systému. Vědecká komunita studii vesměs ignorovala (Harvey 1997, 178-179).

Druhým, a to závažnějším důvodem mohl být fakt, že Clémence-Auguste Royerová stála bezpochyby na počátku pro- 
cesu, který př́rodovědnou teorii proměnil v extremistickou politickou ideologii. Z hlediska morální antropologie Clémence-Auguste Royerová použila Darwinovy teze $\mathrm{k}$ tomu, aby vyvrátila Rousseaův odkaz. Její otevřené zavržení humanistické tradice ve jménu vědy a pokroku představovalo z hlediska vývoje rasové ideologie novátorský, ale provokativní krok, na který navázal ve Francii především Georges Vacher de Lapouge. Za pomoci tezí Charlese Darwina Royerová obrátila historickou perspektivu předloženou Arthurem Gobineauem v Pojednání o nerovnosti lidských ras (1853-1855) a učinila $\mathrm{z}$ árijské vize dějin revitalizační politický program. Svět bude podle jejího mínění spasen zrozením nové árijské aristokracie, jejíž výzbrojí bude věda a ideologií liberalismus a pokrok (Budil 2015, 856-857). To, že se étosu rasové revoluce zmocnili na počátku dvacátého století stoupenci autoritářských a totalitních hnutí (Burrow 2003, 111-112), zastřelo skutečnost, že myšlenka rasové hierarchie nebyla ve druhé polovině devatenáctého století $\mathrm{v}$ rozporu s ideologií liberalismu a progresivismu, jak názorně ukázal intelektuální vývoj Clémence-Auguste Royerové. Hannah Arendtová (1996) nebo Stephen Jay Gould (1997), kteři mezi „otce moderního vědeckého rasismu“ zařadili např́klad excentrického a marginálního literáta Arthura Gobineaua, toto „pochybeni““ demokratické politické kultury ve svých textech pominuli.

\section{LITERATURA}

Arendtová, Hannah (1996): Původ totalitarismu. Praha: OIKOYMENH.

Beecher, Jonathan (1986): Charles Fourier. The Visionary and his World. Berkeley: The University of California Press.

Bernardini, Jean-Marc (1997): Le darwinism social en France (1859-1918). Fascination et rejet d'une idéologie. Paris: CNRS Éditions.

Budil, Ivo (2014): Alfred Russel Wallace, William Rathbone Greg and the Origin of Social Darwinism. West Bohemian Historical Review 2(2):59-76.

Budil, Ivo (2015): Triumf rasismu. Praha: Triton.

Budil, Ivo (2015a): Clémence-Auguste Royer and the Rise of Aryan Ideology. West Bohemian Historical Review, 3(1), 15-27.

Burrow, J. W. (2003): Krize rozumu: Evropské myšlení 1848-1914. Brno: Centrum pro studium demokracie a kultury.

Clark, Linda (1981): Social Darwinism in France. The Journal of Modern History, 53(1), 1025-1044.

Conry, Yvette (1974): L'Introduction du darwinisme en France au XIXe siècle. Paris: Vrin.

Darwin, Charles (1862): De l'Origine des Espèces par Sélection Naturelle ou des Lois de Transformation des Êtres Organiseés. Paris: Guillaumin et $\mathrm{C}^{\mathrm{ie}}$.

Darwin, Charles (1970): O původu člověka. Praha: Academia.

Fraisseová, Geneviève (1985): Clémence Royer: philosophe et femme de science. Paris: Éditions de la Découverte.
Gould, Steven Jay (1997): Jak neměřit člověka: Pravda a předsudky v dějinách hodnocení lidské inteligence. Praha: Nakladatelství Lidové noviny.

Greg, William Rathbone (1868): On the failure of „natural selection“ in the case of man. Fraser's Magazine, 78(455), 353-362.

Harvey, Joy Dorothy (1997): Almost a Man of Genius: Clemence-Auguste Royer. Feminism and Nineteenth-Century Science Lives of Women in Science. London: Rutgers University Press.

Hawkins, Mike (1997): Social Darwinism in European and American Thought 1860-1945. Nature as model and nature as threat. Cambridge: Cambridge University Press.

Nigoul, Toussaint (1887): Pascal Duprat, sa vie, son oeuvre. Paris: E. Dentu.

Parker, C. J. W. (1981): The Failure of Liberal Racialism: The Racial Ideas of E. A. Freeman. The Historical Journal, 24(4), 825-846.

Royerová, Clémence-Auguste (1862): Théorie de l'impot ou La dime sociale. Paris: Guillaumin et $\mathrm{C}^{\mathrm{ie}}$.

Royerová, Clémence-Auguste (1870): Origine de l'Homme et des Sociétés. Paris: Victor Masson et fils.

Royerová, Clémence-Auguste (1877): Deux hypothèses sur l'hérédité. Paris: Ernest Leroux.

Royerová, Clémence-Auguste (1881): Le Bien et La loi morale. Paris: Librairie Guillaumin et $\mathrm{C}^{\mathrm{ie}}$.

Royerová, Clémence-Auguste (1900): La Constitution du monde, Dynamiques des atomes, Nouveaux principes de philosophie naturelle. Paris: Librairie C. Reinwald.

Royerová, Clémence-Auguste (1901): Histoire du ciel. Paris: Librairie C. Reinwald.

Wallace, Alfred Russel (1864): The Origin of Human Races and the Antiquity of Man deduced from the theory of „Natural Selection“. Journal of the Anthropological Society, 2(5), clviii-clxxxvii.

Wells, D. Collin (1907): Social Darwinism. The American Journal of Sociology, 12(5), 695-716.

\section{AUTOR}

Prof. RNDr. Ivo Budil, Ph.D., DSc. (1965) vystudoval Přírodovědeckou a Filozofickou fakultu Univerzity Karlovy v Praze. Působí na Metropolitní univerzitě Praha. V roce 2006 byl na základě úspěšného jmenovacího řízení na Př́rodovědecké fakultě Masarykovy univerzity v Brně jmenován profesorem v oboru antropologie. Ve stejném roce mu Vědecká rada Akademie věd České republiky udělila vědeckou hodnost doktor historických věd (DSc). Zakladatel a emeritní děkan Fakulty filozofické (do 3. 1. 2005 Fakulty humanitních studií) Západočeské univerzity v Plzni, kde dvacet let působil jako vedoucí katedry, proděkan a prorektor. Je autorem dvanácti knih a přibližně dvou set padesáti odborných studií a popularizujících statí. Je nositelem Výroční ceny Nadace Josefa Hlávky za knihu Za obzor Západu (2002), SVU Fellow for the professional achievements in the area of the social sciences (2003), Pamětní medaile Fakulty filozofické Západočeské univerzity v Plzni (2009) a Medaile Vojtěcha Suka udělenou Ústavem antropologie Př́rodovědecké fakulty Masarykovy univerzity v Brně za „vynikající příspěvek k rozvoji české antropologie“ (2009). Žije v Praze a má tř́i děti. 